\title{
The Living Conditions of Syrian Asylum Seekers in Jordan's Governorates Outside Camps and the Motives to Immigrate to Europe
}

\author{
Lina Taysir Alzouabi ${ }^{1} \square$ and Ayat Jebril Nashwan ${ }^{2}$ \\ ${ }^{1}$ Mellon Fellowship Program, Columbia Global Centers, Amman, Jordan \\ ${ }^{2}$ Head of Sociology and Social Work Department, Yarmouk University, Jordan
}

$\square$ Corresponding Author: Lina Taysir Alzouabi, E-mail: linazouabi@gmail.com

\begin{tabular}{|c|c|}
\hline ARTICLE INFORMATION & ABSTRACT \\
\hline Received: 20 October 2021 & Since the Syrian crisis began ten years ago, 5.6 million Syrians have been forced to flee \\
\hline Accepted: 14 November 2021 & to neighboring countries. Jordan is not a member of the 1951 Geneva Refugee \\
\hline Published: 25 November 2021 & convention, so Syrians are treated as asylum seekers rather than refugees. This study \\
\hline DOI: 10.32996/jhsss.2021.3.11.7 & $\begin{array}{l}\text { explores Syrian asylum seekers' experiences and challenges in Jordan, including the } \\
\text { sectors of housing, education, healthcare services, and employment to understand why }\end{array}$ \\
\hline KEYWORDS & they are motivated to seek asylum in Europe. Through semi-structured interviews with \\
\hline $\begin{array}{l}\text { Immigration, Syrian asylum } \\
\text { seekers, Jordan, living conditions, } \\
\text { Push factors, Pull factors }\end{array}$ & $\begin{array}{l}30 \text { Syrian asylum seekers living in four Jordanian governorates outside camps, the goal } \\
\text { is to elucidate the drivers that motivate them to seek asylum in Europe. The findings } \\
\text { emphasize the importance of education and work permits both of which are } \\
\text { considered major push factors or drivers for immigration. The narratives provide a } \\
\text { contextual understanding of the immigration crisis from the voices of the refugees } \\
\text { themselves, which in turn will contribute to the knowledge base of immigration } \\
\text { literature and enhance the support for the Syrian asylum seekers in the host community } \\
\text { of Jordan. }\end{array}$ \\
\hline
\end{tabular}

\section{Introduction}

Ten years have been since the start of the Syrian crisis causing 5.6 million Syrians to flee out of their country to neighboring ones (UNHCR, 2020). The estimated number of registered Syrian asylum seekers in Jordan is 664,603, where 537,114 (81\%) are out camps in urban areas (Syria Regional Refugee Response, 2021). Jordan is not a signatory in the 1951 Geneva Refugee Convention of the United Nations or 1967 Protocol; therefore, Syrians are treated as asylum seekers, not as refugees who may motivate them to seek resettlement. According to a Memorandum of Understanding (MOU) signed in 1998 between the UNHCR and the Jordanian government, the UNHCR must find a resettlement country for them. Supposedly, Syrians will stay in Jordan for six months after being accepted as asylum seekers. So, the status between being a refugee and an asylum seeker varies according to the criteria established by the 1951 convention, "Asylum seeker describes someone who has applied for protection as a refugee and is awaiting the determination of his or her status. The refugee is the term used to describe a person who has already been granted protection" (UNESCO, 2017).

A Jordanian government official confirmed in an International Labor Organization (ILO) report in 2015 that Jordan refuses to accept Syrians as refugees (Saliba, 2016). This implies that; access to education, healthcare, and legal employment is restricted. The growing lack of future perspectives and frustration over the current situation led many to think about further immigration. The rising desperation that pushes people to leave the Middle East, suggests that they can only continue to move forward (Hartberg, 2016). For a considerable number of Syrians, European countries are among the main destinations (Hartberg, 2016). Those who can afford to, often try to reach one of the European countries to apply for asylum there. The services that Europe offers, such as better access to healthcare, education, accommodation, and employment as well as the aspiration of better living conditions according to the migration policy that some European countries follow, are described by many as a driving motivation.

Copyright: (c) 2021 the Author(s). This article is an open access article distributed under the terms and conditions of the Creative Commons Attribution (CC-BY) 4.0 license (https://creativecommons.org/licenses/by/4.0/). Published by Al-Kindi Centre for Research and Development, London, United Kingdom. 
To better understand the large migratory movements and the influx of refugees, it is necessary to trade with the situation in the transit countries, which is prompting many to continue migrating. In this regard, this study aims to gain more comprehensive insights into the living conditions and personal migratory experiences of Syrian asylum seekers, which most studies excluded as the most effective actor. It is not just about promoting understanding and empathy with them but also about improving the potential support services. It further identifies the gaps of the factors that push Syrian asylum seekers to secondary immigration, besides advocating for a deeper analysis of motivations and aspirations of Syrian asylum seekers living in Jordan, bringing a sense of humanity to the study.

\section{Literature Review}

The Jordanian government responded to the increasing number of refugees coming to Jordan due to the worsening situations in Syria by changing its policy towards Syrian asylum seekers. The memorandum specifies that "asylum-seekers may stay in Jordan pending refugee status determination (RSD) and allows mandate refugees a maximum stay of six months after recognition, during which a durable solution must be found" (UNHCR, 2018, p.1). Moreover, the report clarifies that Jordan does not automatically acquire refugees "the rights to residency, employment, public education, or health care" (Sadek, 2013, p.5). According to Achilli (2015), this includes the official restrictions on working, increasing rent rates, the interruption of free health care, and the verification process that aims to restrict Syrian asylum seekers' freedom of movement. Furthermore, Syrian refugees receive just a prima facie status in Jordan (Lenner and Schmelter, 2016).

Under these circumstances, Syrian asylum seekers struggle with limited rights, such as restricted access to education and legal employment. They perceive their living conditions as unexpectedly insecure (Kvittingen et al., 2019). The outbreak of COVID-19 even worsens the situation where many have been unable to gain entry to asylum-seeking countries. Mobility restrictions, border closures, and suspension of commercial flights affect refugees' access to host countries and delay legal procedures (Diab, 2021). According to Jordan's Department of Statistics (DoS), a report on the living conditions of Syrian refugees residing in camps and out camps present the recent statistics from November 2017 and January 2018, three out of ten people are considering relocating to Europe (Tiltnes, Zhang, and Pedersen 2019). However, circumstances are deteriorating and the lack of abilities and opportunities in Jordan leaves many asylum seekers to consider secondary migration (Kvittingen et al., 2019). European countries are a major destination for many refugees, especially Syrians (Crawley and Hagen-Zanker, 2019). Neumayer (2005a) believed that the three factors in attracting asylum applications are identified as "GDP, the refugee stock and the recognition rate.... Respectively these pull-force factors reflect economically, family/network/social, and administrative conditions in the EU country" (as cited in Keogh, 2013, p.372).

Tanner (2014) reviewed the literature and come to a conclusion that pull factors are more important than push factors and underlined that economic factor was the leading ones among other factors. Haider (2016) summarized seven main explanatory factors contributing to Syrian secondary immigration towards Europe:

1.Existential insecurities,

2.Financial burdens and poverty,

3.Unsatisfying aid distribution,

4. Residency issues and limited access to public services,

5.Poor educational perspectives,

6. The feeling of alienation and challenges in social integration

7.The desperation with regards to the future and the positive image of life in European countries.

Similar factors also come to the fore in studies investigating the pull and push factors of immigration to Europe of the Syrian refugees staying in Turkey (Kouider, 2021) and Lebonan (Hager, 2021).

Young persons or families who are particularly affected by the worsening circumstances and who are unable to return to their wartorn homeland consider migration to Europe and often they already have some contact persons in Europe (Kvittingen et al., 2019). Hartberg, in research for the Norwegian Refugee Council (NRC), indicates that Syrian refugees are stuck between critical choices: to stay in host countries with minimum access to services, to confront death by turning to Syria, or to travel onward to Europe. NRC research concluded that "In Jordan, 50 percent of Syrian refugees surveyed by NRC at the end of 2015 said that they were intending to leave because they saw no future" (Hartberg, 2016, p.1).

Lyngstad (2015, p.3), in her study, aimed to understand "why and how young Syrian refugee males in Jordan prepare for irregular travel to Europe". She infers that there are differences between the self-narrative and the narrative of the real situation that can cause secondary immigration when in the preparation process of onward movement, the social status embedded in an individual's social network is important. But for the majority of refugees, it is impossible to immigrate to Europe because they cannot afford a 
regular immigration way to Europe. The majority of Syrians with sufficient financial means choose to immigrate. The difficulties in obtaining a visa for legal entrance into a European country, and changes in European border policies against refugees, complicate the procedure (Lenner and Schmelter, 2016). Many are therefore forced to choose unsafe and dangerous routes to Europe; oftentimes, they have to settle temporarily in other countries before continuing to their destination. Hence, refugees have become a target for smugglers and traffickers (Mandic, 2017).

Once the decision to immigrate has been made, information about possible routes as well as life in Europe has often been spread across social media and social networks. Social media has become a common and easier way of communication among asylum seekers to make decisions to emigrate and where (Dekker et al., 2018). These media coverage and informational exchange through migrant networks play an important role by propagating an illusional image of unrealistic migrant opportunities in European countries. Many refugees had high hopes, aspirations, and dreams while coming to Europe and applying for asylum in these countries. Syrian asylum seekers who confront difficulties and cannot turn to Syria are attracted to Europe by "its reputation for respecting human rights and the rule of law and its far greater prosperity" (Groth, 2016, p.3). However, Syrian refugees across Europe as a whole are not given the same protections and rights. Adrian Edwards, a spokesperson for the UNHCR, stated that although most countries process claims and offer protection for Syrians, the protection approaches and the form of status and entitlements differ significantly (as cited in Fargues and Fandrich, 2012). Therefore, this study aims to explore the living conditions of Syrian asylum seekers settling in four Jordanian governorates in order to define pull and push factors that motivate them to immigrate to Europe.

\section{Method}

This study used qualitative research methods to help disclose and freely express the participants' experiences of the topic. Qualitative research is used to obtain more detailed information about a social phenomenon. Qualitative research designs are used to reach in-depth information, to understand and explain the phenomenon through experiences, without aiming to generalize in explaining the phenomenon (Creswell, 2002). Data that is collected through qualitative data has a textual characteristic. Focus group discussions, observations, participant observations, in-depth interviews, diary entries are some of the data collection tools which are common in qualitative research (Smith and Smith, 2018). To get detailed information about the push and pull factors that affect Syrian refugees' decision to move to Europe, an in-depth interview was selected as a data collection tool. Audiorecorded interviews and some transcripts of those who refused to record, which consist of the main source of data for the study, were held between the Arabic-speaking researchers and the participants. Institutional review board (IRB) approval was received from Yarmouk University before the implementation of the study.

The researchers used the "Purposive Sampling" technique which is applied when the researcher selects the samples based on who $\mathrm{s} /$ he considers the participant to meet the requirements of the research (Taherdoost, 2016). Interviews are widely used in migrationrelated studies, especially in the European context (Fedyuk and Zentai, 2018). That is because interviews grant the participants the control to share life-story, experiences, perspectives, feelings, and knowledge according to the researcher's agenda. The interview is flexible and can be conducted at a convenient time and place where the interviewee feels safe without any pressures or repercussions (Zapata-Barrero and Yalaz, 2018).

\subsection{Selection of participants}

Participants were recruited via the snowball method where participant leads to another. Inclusionary criteria included being a Syrian asylum seeker in Jordan who has asylum seeker status after the uprising conflict in Syria in 2011. Syrian families and youths from different Syrian governorate backgrounds, aged 18 to 60 years are being asked to participate in the interviews which lasted between 30 to 45 minutes.

Due to the impact of the COVID-19 outbreak and associated restriction of movement, some of the participants were interviewed online via suitable platforms. A copy of the consent form to the participants was sent or given to be signed and received before the interviews.

All participants were Syrian asylum seekers who sought refuge in Jordan after the uprising crisis in Syria in $2011(n=30)$. All of them live out camps in urban areas and are holders of the UNHCR certificates. The participants were between 18-60 years old. The number of participants was distributed among 4 governorates based on the overall number of Syrian asylum seekers in Jordan. According to UNHCR, 664,603 Syrian asylum seekers are respectively spread out; Amman: 195,626, Mfraq: 165,093, Irbid: 136,462, Zarqa: 97,153 (Syria Regional Refugee Response, 2021). The number of married and individuals was divided by the overall participants' number in each governorate. Participants were from different Syrian governorates and the largest number of them 
was from Dara. A statistical report on UNHCR registered Syrians indicates that 39.9\% of Syrians are from Darra (Jordan: Statistics for Registered Syrian Refugees, 2021). Most of them have spent no less than 8 years in Jordan (Table 1).

Table 1. Demographic characteristics of Syrian asylum seekers

\begin{tabular}{|c|c|c|c|c|c|c|c|c|}
\hline Age & $\begin{array}{l}\text { Marital } \\
\text { status }\end{array}$ & Gender & $\begin{array}{l}\text { Syrian } \\
\text { background }\end{array}$ & $\begin{array}{l}\text { Jordanian } \\
\text { Governorate }\end{array}$ & $\begin{array}{l}\text { Prior } \\
\text { countries }\end{array}$ & $\begin{array}{l}\text { Way of entry } \\
\text { to Jordan }\end{array}$ & $\begin{array}{l}\text { Duration of } \\
\text { residency in a } \\
\text { camp }\end{array}$ & $\begin{array}{l}\text { Years in } \\
\text { Jordan }\end{array}$ \\
\hline 56 & Married & & Aleppo & Amman & - & Regular & - & 9 \\
\hline 32 & Single & $\mathrm{F}$ & Damascus & Amman & - & Regular & - & 10 \\
\hline 40 & Divorced & & Darra & Amman & - & Irregular & 2 weeks & 8 \\
\hline 25 & Married & & Darra & Amman & - & Irregular & 2 days & 8 \\
\hline 19 & Single & $M$ & Homs & Amman & - & Irregular & - & 8 \\
\hline 35 & Married & & $\begin{array}{l}\text { Damascus } \\
\text { Countryside }\end{array}$ & Amman & $\begin{array}{l}\text { Saudi } \\
\text { Arabia }\end{array}$ & Regular & - & 10 \\
\hline 33 & Single & $M$ & Darra & Amman & - & Regular & - & 10 \\
\hline 27 & Married & & Homs & Amman & Lebanon & Regular & - & 8 \\
\hline 23 & Single & $\mathrm{M}$ & Darra & Amman & - & Regular & - & 8 \\
\hline 23 & Single & $M$ & $\begin{array}{l}\text { Damascus } \\
\text { Countryside }\end{array}$ & Amman & - & Regular & - & 8 \\
\hline 27 & Widow & & $\begin{array}{l}\text { Damascus } \\
\text { Countryside }\end{array}$ & Mfraq & - & Irregular & 1 day & 8 \\
\hline 27 & Married & & Latakia & Mfraq & - & Regular & - & 4 \\
\hline 19 & Single & M & Idlib & Mfraq & - & Regular & - & 10 \\
\hline 54 & Married & & Homs & Mfraq & - & Irregular & 20 days & 8 \\
\hline 26 & Married & & Idlib & Mfraq & - & Regular & - & 10 \\
\hline 24 & Single & M & Homs & Mfraq & - & Regular & - & 8 \\
\hline 31 & Divorced & & Homs & Mfraq & - & Irregular & - & 8 \\
\hline 32 & Married & & Homs & Mfraq & Lebanon & Regular & - & 8 \\
\hline 54 & Single & $\mathrm{F}$ & Darra & Irbid & - & Regular & - & 9 \\
\hline 45 & Married & & Homs & Irbid & - & Regular & - & 9 \\
\hline 26 & Married & & Darra & Irbid & - & Irregular & 3 days & 9 \\
\hline 48 & Married & & Homs & Irbid & - & Irregular & 2 weeks & 8 \\
\hline 22 & Single & M & Darra & Irbid & UAE, Egypt & Regular & - & 9 \\
\hline 22 & Single & M & Darra & Irbid & - & Regular & - & 8 \\
\hline 42 & Widow & & Darra & Irbid & - & Irregular & 1week & 8 \\
\hline 22 & Single & $\mathrm{M}$ & Darra & Zarqa & - & Irregular & 12 hours & 8 \\
\hline 23 & Single & $\mathrm{F}$ & Darra & Zarqa & - & Irregular & 2 weeks & 9 \\
\hline 50 & Married & & Hama & Zarqa & - & Regular & - & 8 \\
\hline 40 & Married & & Darra & Zarqa & - & Irregular & 5 years & 9 \\
\hline 41 & Married & & Darra & Zarqa & - & Irregular & 7 years & 8 \\
\hline
\end{tabular}

\subsection{Data collection}

To provide in-depth insight into the aspirations of those who have the intention to immigrate to Europe, 30 interviews were conducted with Syrian asylum seekers living in different Jordanian governorates mainly Amman $(195,107)$, Mafraq $(164,531)$, Irbid $(136,190)$, and Zarqa $(96,768)$ that have a large number of Syrians (Syria Regional Refugee Response, 2021). Using the Arabic language, the participants were asked through the guided interview which was developed and designed on standardized openended questions. The semi-structured interview was used because it is more organized to minimize probe questions and bias during the interview as well as collects data of same questions from all respondents to be able to compare between them.

\subsection{Data analysis}

The recorded interviews were transcribed in the Arabic Language. The two researchers read the transcripts independently. The data were analyzed using an inductive method, which allowed researchers to identify early codes and themes. Each researcher read the data three times and examined the transcript line by line, developed a preliminary coding system for the data, and organized the codes into possible topics. To improve the study reliability, the researchers reviewed the transcripts, re-coded extract 
data, and coded any further data into themes (Braun and Clarke, 2006). Related quotes that represent participants' narratives were reviewed by research members as they exemplify their thoughts and experiences.

\section{Results}

According to the analysis, there are four themes obtained. The themes are named "Living conditions of Syrian asylum seekers in Jordan", "Push factors of immigration to Europe", "Pull factors and motives to Europe", and "Routes of immigration".

\subsection{The living conditions of Syrian asylum seekers in Jordan}

The first section of the interview is about the living conditions in Jordan related to housing, education, employment, and health. These questions were raised to gain a better understanding of the current situations of Syrian asylum seekers and how that affected their motivations to immigrate. Jordan viewed the fleeing Syrians as guests, not as refugees' contrary to the 1951 convention and its protocol. However, Jordan's policies have restrictions on refugees' freedom of movement, residency, employment, housing, education, and healthcare (Yahya, Kassir, and El-Hariri, 2018).

\subsubsection{Housing}

In terms of housing, renting, and the challenges the participants found in affording it, they stated that they were tenants, and most of them stayed in the same governorate since they arrived. During their time in Jordan, they lived in at least two houses, with the maximum number being nine. Crowded houses where extended families live together in the same house are common. Haifa stated, "We are eight persons in the same family, we live in this small apartment which consists only of two rooms with one bathroom." The World Bank Jordan housing sector review (2018) estimates that 6 percent of all households had overcrowding, described as more than 2.9 people per room in 2015.

Kamila said, "3 families are living together in this house, my family and my two married sons." Jordan's quantitative housing deficit, according to the World Bank (2018), is up to 10\% on a national basis. According to the 2015 Census, 73 percent of the residents were foreign families, mostly Syrians and Egyptians, who shared apartments with two or three other families. Almost half of the participants said that the buildings and houses they dwelled in were not good enough. In contrast, five of the participants were totally dissatisfied with the houses' worsening conditions.

The majority of the participants involved had to rent in old, decaying buildings or houses with issues such as damp, inadequate facilities and leaked water in the winter. Some families were forced to rent small houses, far away from services, which resulted in high transportation costs. Inquiring about any rent assistance, the majority stated that they had never been afforded any kind of rental assistance. Three participants had at least a one-time assistance.

\subsubsection{Education}

When asked about education, almost all the interviewees indicated that access to formal educational services for children was free of charge. However, according to a UNICEF report, the primary school enrollment rate for Syrian refugee children is ten percentage points lower than the national average, at just $87 \%$ (CARE, 2021).

Twenty-two of the participants had only achieved either elementary or secondary level without gaining the General Secondary Education Certificate (Tawjihi) in Syria. Some were not able to continue their education due to financial reasons as supporting their families. Mohammad N. explained, "No, I couldn't continue [his education] here in Jordan, I had to quit my school due to financial conditions to secure my livelihood. I don't have time to study."

Tamer said that he was only in third grade when he came and had lost one school year, which was the fourth grade because of the school registering procedures. Tamer clarified, "I resume my study from the fifth grade to the first year of high school, where I had to leave it so that I could support my family with the household expenses."

Access to higher education for Syrians is limited; compared to $48.1 \%$ of Jordanian youth, only $35.8 \%$ of Syrians are able to access further education (CARE, 2021). Six of the participants claimed that the lack of scholarships in Jordan was preventing them from completing their studies and that even if they were available, they were limited due to difficult conditions. "I have two daughters who achieved well on Tawjihi but were unable to pursue a university education due to a lack of scholarships, and I am unable to teach them at my own expense," said Najah.

\subsubsection{Health}

Since 2014, Syrians registered as asylum seekers had to pay as uninsured Jordanian for secondary health services, while those without $\mathrm{MOI}$ cards (Ministry of Interior) had to pay as foreigners for healthcare. Fifteen of the interviewees stated that they didn't receive healthcare services. However, when they needed it, they resorted to treatment at their own expense. Ammar is adiabatic. 
Concerning reaching the healthcare services, he commented, "Not available, and I am a first-degree diabetic. I get my treatment at my own expense."

While the $\mathrm{MOI}$ card allows them to access public healthcare, it is limited to the district in which the card is provided (Yahya, Kassir, and El-Hariri, 2018). Kamila clarified, "Healthcare is not available because the UNHCR certificate is affiliated with Zaatari camp, and so our treatment is only inside the camp, in case we need treatment, it is at our own expense".

Twelve participants indicated that services were only available in a very limited way through certain organizations, clinics, or governmental hospitals. The medical services were limited and not always available, in addition to the fact that medications were not always available or dispensed to them. "Medication is fairly available; we do not receive a full treatment. My mother has diabetes, and she is given a different type of medication every month, which makes her tired, so I had to buy the medicine myself," said Sultan.

\subsubsection{Employment}

Jordan's unemployment rate is high and rising, owing to the COVID-19 crisis. According to Assessment Capacities Project (ACAPS) February 2020 review, the average unemployment rate among all residents in governorates with the highest influx of refugees has grown by around $3.3 \%$. Syrians' unemployment rate has also risen to $65.1 \%$, where, $45 \%$ related that to the lack of opportunities, $40 \%$ believe that COVID-19 is a barrier (CARE, 2021). "I have been jobless for two years; I used to work in sales, but they fired me in 2019, and I am still looking for work," said Osama.

Twenty of the participants are unemployed or have lost their jobs recently, so they depended on members of their families. Some of them used to work in professional jobs or the humanitarian fields.

"My husband works at a vegetable market. I do not work and am not looking for work; my husband would not allow me to work in professional fields in Jordan because of the situation and what I would be exposed to, as well as the fact that my children are young; however, I believe the situation would have changed if I had completed my education" pointed Ghada.

While looking for a job, thirteen participants mentioned the scarcity of job opportunities in Jordan as a result of the current economic situation, and several said that obtaining a work permit is a barrier to employment.

"As for the legal status, it is very difficult. I had changed a lot of jobs, as I worked in a library, printing, publishing, and design as well, all of them are illegal. My ambition is to work in journalism, but the conditions are extremely challenging. I had to borrow money to pay for transportation to join a training facility to get a job after the training. I work now without a permit, legally I am not a journalist, so any problem that I may encounter in my work I will bear its consequences" clarified Ammar.

Long hours, low wages, and cost of transportations were common obstacles that participants faced in searching for a job.

"From a personal point of view, I must search if the work is suitable for me as a girl and mother, for example, to work in factories, I am only allowed in the production department, but for me, I cannot work except in the administrative department, and this is not allowed for me as a Syrian, this field is only for the people of the country [Jordan]. On the other hand, for example, I might charge only 200 JD and not enough for transportation, in addition to long distances" stated Eleven.

\subsection{Push factors of immigration to Europe}

The second section sheds light on the challenges and the motives that push Syrian asylum seekers in Jordan to immigrate to Europe. In renting a house, high rent cost is among the most serious difficulties twelve participants faced.

"Owing to the high rent costs, it is difficult to find a suitable house. Furthermore, the house itself is not suitable for dwelling. We had been internally displaced in Syria for 9 months, and our financial situation was dire, so we were moving from a house to another in Jordan, searching for lower rent costs" commented Israa.

According to ACAPS review (2020), "Syrian refugees living outside of camps spent more than two-thirds of their monthly household budget on shelter, leaving few resources for food, health or education." Twenty-five participants said that they found difficulties in paying the rents, especially during the COVID-19 outbreak. As a result, they resorted to a variety of mechanisms to negotiate with the house owner to delay their rent payments, borrow money, or use the voucher for food to pay the rent. Haifa 
stated that "I find it very difficult to pay the rent even if I have to borrow." Abed al-Salam added, "It was very difficult for me to pay the monthly rent because I was at risk of being evicted if there was a delay."

The majority of the participants stated that at least two family members had to work to help pay for household expenses. Rawan had to support herself and her family, "I and my divorced aunt are attempting to work full-time, and my 18-year-old brother is practicing the occupation of car mechanics and earning a meager wage; we all contribute to the house's expenses and rent."

Various challenges appeared when started talking about education, an air of sorrow and frustration filled the surrounding. Although access to education for aged-school children is free in Jordan, still families struggle to continue their children's education. Financial difficulty, child labor, costs required for schooling, far distance, and overcrowded classes are key factors for dropping out of school (Jordan INGO Forum (JIF), 2018). Some interviewees, who have children at schools, stated that the lack of quality education in public schools, as well as the differences in curricula between Syria and Jordan, and the fact that schools for Syrians were inefficient when compared to schools of the first period in the morning. Additionally, the cost of transportation, bullying, and the high price of private lessons, especially at the secondary level (Tawjihi) were difficulties they had to deal with. Israa has one child, who was enrolled in public schools but later opted out to attend a private school, explained,

"The educational opportunities in public schools are very, very poor. I live near a school designated for Syrians in the evening. They only study for 3 hours, and there is no good education. In addition, schools include a variety of environments, and anyone may be exposed to my son. This has already happened, as he was beaten, I could not complain about the pretext that I am Syrian and will not get anything".

Age, lack of official documents, constant mobility, and the high costs of the university on the one hand and fulfilling the basic needs of their families prohibited seven participants from continuing their education. Tareef said, "My children did not continue their education due to financial constraints, when we arrived in Jordan, we had nothing, they had to work for the family. At that time, we didn't have any assistance."

Muhannad Al-Khatib, the Ministry of Higher Education spokesman, stated that "Most of the Syrian students register through some of the international donors available in Jordan to provide scholarships in private universities."

However, only four of the interviewees were offered scholarships to continue their studies, two with full scholarships and the others with vocational training and a partial scholarship.

"Syrian refugee students are treated the same as Arab or foreign students in terms of legal procedures. In addition, the higher education ministry provides facilities for cooperation with students in terms of giving them time to bring official papers from Syria. These facilities continued from the beginning of the crisis until now. In addition, there are expatriate offices at the university that can help them by bringing their documents" added Al-Khatib.

Commenting on that Ammar said, "The opportunity for higher education is available, but the financial side is not. Since the Syrian student is dealt with as a foreigner rather than a Jordanian, the costs outweigh the student's ability to pay."

Lack of access to healthcare services and the high cost of private clinics create also challenges for Syrians in Jordan. The expense of healthcare is the most significant impediment for refugees needing such services in host communities; cited by $74 \%$ of Syrian households as a justification for not seeking chronic disease treatment (JIF, 2018). Almost half of those interviewed believed that healthcare was difficult to get by, as a result, they turned to self-paying prescriptions. Ammar sadly said,

"My first daughter's birth was a traumatic and costly experience. She was born in her seventh month and had to remain at incubator prematurity. I had to pay a total of 2,700 JD, which I had to borrow because she was uninsured. My daughter passed away and I stayed for a long time paying off the debt. In addition, I am a diabetic and was exposed to Coronavirus. I have diabetic foot inflammation also. Since I do not have health insurance, I had to pay for treatment at a private clinic at my own expense."

By asking about their urgent and critical experiences in reaching healthcare services, requests for treatment were refused by different organizations. More than ten participants remained on the waiting list, while some couldn't wait any longer and had to seek treatment in private clinics and hospitals, Nwaf said, 
"During her twin pregnancy, my wife had suddenly a bag of water on the kidney. We had to wait too long to get permission from organizations and associations to receive treatment. Putting her life and the lives of the fetuses at risk, I had to pay for the surgery on my own money."

The majority of the issues are related to the high cost of healthcare services, including transportation and the ability to buy medications, as well as low service quality, with some patients receiving simply painkillers as treatment. The cost of accessing public health remains the most significant obstacle for $70 \%$ of respondents according to Jordan Response Plan (JRP) assessment in 2020-2022.

Three of the female participants claimed that they were bullied while seeking medical treatment. As Fayza who was bullied by the nurses and doctors because of her excessive weight, Ghada said,

"The services provided during childbirth were appalling, and their words were inappropriate. I was offended, so I just kept quiet to satisfy them and to end the labor. During my birth, I asked for a female doctor to examine me, however, they refused to state that only a male doctor would be present and that if I wanted a female doctor, I could go to a private hospital at my own expense".

Without work permission, Syrian asylum seekers have no legal right to work. Labor Ministry's Spokesperson Mohammad al-Zyoud said that 38754 was the total of issued (WP's) work permissions for Syrians in 2020 in the economic sectors; 36115 male, 2639 female, 38,740 WP's in the construction sector, and 82,544 WP's in the agriculture sector. In addition, al-Zyoud added that beneficiaries of labor-intensive projects and cash-for-work programs have temporary work permits that last no more than six months. The majority of participants were working without permits so far for different reasons as issue costs, closed employment sectors, required documents, inability to keep up with constant work, and the employers' reluctance to issue them a permit.

Others indicated that working as paid volunteers did not need them to have WPs, while others stated that their WPs (construction and agriculture) were incompatible with their occupations. "My son had a construction work permission whereas he worked in a factory. He didn't pay anything; it was issued by the factory's owner," said Haifa.

Most interviewees shared the same challenges which revolved around long working hours, low wages, far distances, transportation difficulties, exploitation (not getting their salaries), and closed sectors. Israa, who worked with different organizations, stated,

"As a Syrian, I need Wasta [medium] to work. Even though most organizations require Syrians and Jordanians to work together, it is always a priority for the Jordanians. Regardless of my prior experiences, I would be accepted as a volunteer if approved, consequently, there will be no health insurance or social security."

These challenges were playing a critical role in pushing Syrian asylum seekers to immigrate or planning for immigration. Most of them believe that seeking refuge will enable them in obtaining legal and permanent jobs where all their rights are preserved. When questioned if these factors played a role in his decision to immigrate, Osama replied,

"Yes, they push you to immigrate; but, if Syrians are allowed to work, we will not immigrate; regrettably, we are restricted in terms of getting a driver's license and a car here. Work is limited, except for some occupations. For the past two years, I have not worked. Since there aren't enough job opportunities, I'd like to immigrate. Two years ago, I made my decision".

Most of the participants assure that education comes as a priority for them to immigrate. It is not only the quality of primary education but also gaining access to colleges after high school.

"The Syrians are faced with two choices: dropping out of school in exchange for jobs or considering immigration. Many Syrians have been forced to immigrate due to health issues, but this is a weaker reason. Many Syrians have given up their health in exchange for educating their children, especially those around the age of 35, who have abandoned their education or health as a priority in favor of building and creating a future for their children" clarified Mohammad N.

During COVID-19, the majority of participants expressed an increased desire to immigrate to Europe. The immigration procedures of other participants have been postponed. Mohammad A. added,

"Most Syrians do not have money at the time of the ban, but in Europe, the government would be responsible for me as a refugee." Sultan regretfully stated, "Over the ban's days, the situation deteriorated to the point that I couldn't even get bread for my family, prompting me to seriously consider immigration".

Several factors influenced Syrians' decision to emigrate. Without minimizing the importance of many elements, some stood out more than others. Those who intended to immigrate for legal work and those who intended to immigrate for educational 
opportunities made up nearly equal percentages. Although some respondents prioritized working challenges, others showed that education was a significant factor in their immigration decision. What was remarkable about these discussions was that, while the majority of participants sought the ability to work legally in different sectors, still this was not the key driver of immigration. According to Mohammad $\mathrm{H}$, a better quality of education and getting access to universities were the top priorities for Syrian asylum seekers in Jordan. "I would not leave for financial or health reasons. We live a decent and respectful life in Jordan, but the development sector[education] in Europe is far larger."

\subsection{Pull factors and motives to Europe}

The protracted process of resettling Syrian asylum seekers in Jordan puts even more strains on Jordan's already stretched finances (Global Forced Migration, 2020). Therefore, it's inevitable that Syrians will struggle to meet their basic needs. As the conflict in Syria approaches its eleventh year, most Syrian asylum seekers are aware that their chances of returning home are decreasing. Consequently, they begin to look further overseas to European countries. In a survey conducted by (NRC) in Jordan at the end of $2015,50 \%$ of Syrian refugees said they planned to leave Jordan because they saw no future; $20 \%$ of them said they would still attempt to reach Europe (Hartberg, 2016).

On average, most of the interviewees have been in Jordan for almost eight years. According to Boulby \& Christie, 2018, in turbulent regions, the first place of asylum may not always be able to provide enough human security (both freedom from fear and freedom from want), forcing refugees to seek asylum in onward or irregular movement in a third country. As the situation worsened and humanitarian supplies became scarce, many Syrians sought to escape these difficulties in Jordan. Vagueness, hesitation, and hopelessness characterized their replies to the query regarding their plans as they had no clear plans. Kamila poignantly expressed that, "If we remain in Jordan, there is no future. My children will waste their efforts in the factories, and so will do my grandchildren after them."

It was discovered that there is a very close bidirectional connection between migration and development by studying the relationships between international migration flows and levels of development (Caselli, 2019). When asked why they desired to move to Europe, common responses emerged. The majority of respondents believed that Syrians would be accepted in Europe and would be able to gain their rights to education, employment, health, and dignity. Others expressed a desire to reunite with their families and start a new, secure life. Faiza said,

"To be in a European country that preserves and respects human rights; education and healthcare rights, as well as social justice, will be secured. In Europe, I assume a Syrian would not be ranked second in the society, but rather a citizen like others."

Therefore, Europe is a popular migration destination for people from Africa and the Middle East because of its distance, safety, and economic stability (Global Forced Migration, 2020).

"Everyone had a goal in mind; some wanted to work, while others wanted to educate their children. Most Syrians quit studying after the Tawjihi [high school] in Jordan because there are no scholarships available. You can study and work in Europe at the same time. In terms of wages, it is set, as it is for every European citizen, but here it is impossible" clarified Eveleen.

According to participants' responses, the key drivers of immigration to Europe are access to education and jobs. Several participants pointed that education played a crucial role in promoting their decision to immigrate. Many Syrians who obtain primary education may not have access to secondary education or are unable to do so. While 63 percent of refugees attend primary school, just 24 percent attend secondary school, compared to an international average of 84 percent (Global Forced Migration, 2020).

"There are educational opportunities available [in Europe]. If you succeed, you will be placed in the appropriate class for your grade, rather than being avoided due to the low rate. Students are encouraged by universities if they are unable to afford their fees" stated Rawan.

Several interviewees explained that asylum seeker status hindered their progress owing to several legal procedures, in addition to Jordan's severe economic conditions and limited resources making it difficult to secure their future. Furthermore, most of them added that the high cost of education is a barrier to achieving their aspiration in learning and developing their life career.

"My current job does not meet my basic needs, and even a Jordanian citizen wouldn't guarantee to secure them. I am always worried about the future because I am unable to secure anything. I cannot study at my own expense, and there are no scholarships available. I don't feel settled as a refugee," Nwaf commented. 
Other participants mentioned that job prospects tempted them to relocate because Europe is a developing continent. "As a single mother with two children, there might be more opportunities for me to work. Where I can work and study at the same time, giving me more time to educate my children" said Evelen.

Once the decision to move forward is taken, various sources of information will be shared. Family, relatives, and friends are to be considered trustworthy sources for them. Koser and Pinkerton (2002) commented on how networks play a key role in spreading information. The authors discovered that social networks were where their informants found the most trusted sources among the internet, agents, formal institutions, and the media (as cited in Brekke and Aarset, 2009). A significant number of the participants has at least someone in Europe. When asked whether they would recommend migration to Europe, the majority of the participants said yes. They believe that Syrian refugees in European countries have achieved their goals and aspirations in terms of schooling, employment, and even luxury. Fadel said, "My family lives in Germany, and they encouraged me to immigrate because they had a better life there, in the sense that they had access to things that we did not have in Syria, like economic opportunities."

Several interviewees stated that social care and assistance for refugees, not being perceived as refugees, and a sense of psychological comfort and stability, as well as the possibility of obtaining a European passport and becoming a European citizen, were all elements that pushed people to immigrate. Health issues, on the other hand, were at the bottom of the list of reasons for immigration. Danish Refugee Council DRC (2016) indicated that the expectations of respect and dignity which participants lack in the host countries are the key motivation for traveling to Europe.

"I've been in Jordan for ten years; it's as I've just arrived. As a refugee, nothing has changed in my life; if I'm in Europe, I'm now a citizen. A Syrian in Europe is provided with social services. If he does not find employment right away, he is taught the language and is prepared for work" concluded Ammar.

\subsection{Routes of immigration}

Limited access to employment and healthcare services, scarce educational opportunities, and shortage of donors' funds led many Syrians to see immigration as a solution to their problem (Achilli, 2015). The large number of refugees who applied for resettlement to Europe in 2019 was Syrians (UNHCR, January - December 2019), while the total number of submissions for Syrians in Jordan was 217 (UNHCR, February 2021). When asked about the potential ways of immigration that participants were considering, almost all of them assured through legal ways; either UNHCR resettlement, family reunification, or scholarships. "I will not immigrate illegally, impossible, because of the risk and high costs" stated Israa.

However, few participants stated that if they were compelled to, they might be forced into illegal immigration, or as a last alternative, if material conditions are available. Knowing the risks of the journey to Europe, still some believe that it is worth it (Haider, 2016). Several participants' acquaintances immigrated illegally, and some of their families were reunited as a result. "My sister's husband immigrated illegally, and she and her family were reunited in Germany. During his two and a half years away, my sister and her children were put under a lot of stress." Mohamad H. commented.

A variety of issues were mentioned in response to a question about regular and irregular immigration challenges, including learning a new language and gaining access to educational facilities, adapting to a new environment, as well as new customs and traditions, and racism based on religion, particularly the issue of wearing (hijab) a headscarf. Faiza clarified, "Language, customs, and cultural variations are all factors to consider, aside from adjusting to the life in Europe (a different life from what I lived in Syria and Jordan)."

Osama also stated, "In terms of culture and religion, a society that is different from ours is acceptable, as long as it gives freedom of choice. We may face discrimination because of our religious beliefs, but there is a legal system in the place."

Others believe they will not confront any or would rather not think about it. Dabia stated, "We can't possibly face any more obstacles than those we faced in Syria and Jordan." While Abed al-Salam hopefully concluded, "I don't want to think about challenges because I'm moving from one situation to another and hoping for a better future."

\section{Discussion and Conclusion}

The findings of the study demonstrate the living conditions of Syrian asylum seekers in Jordan's governorates outside camps and examine push and pull factors that influence Syrian asylum seekers in Jordan to immigrate to Europe. Jordan works under the Memorandum of Understanding (MOU) with UNHCR, which means that residency, work, public education, and health care are not automatically granted to refugees (Sadek, 2013). Most of the participants stated that lack of health services, losing hope, and 
feeling insecure, in addition to house rents, access to education, and legal employment are among the challenges that they experienced most of the time.

Several participants saw that access to legal work especially closed sectors would protect them from exploitation. This made it much more difficult to afford house rentals, which according to them, could consume most of their earnings. Andrew Harper, the UNHCR representative to Jordan, pointed out that one of the reasons that have pushed refugees to move to Europe is that Jordan and the World Food Programme (WFP) in particular have received insufficient support from the international community to help alleviate the crisis' impact. (Malkawi, 2015). The work permit is among the most challenging issues that Syrians confront while searching for work, and as a result, they have been exploited. The majority expressed dissatisfaction with their current situation as well as despair. They believed that heading toward Europe is the best approach to solve the problems.

Furthermore, most participants wish to improve their education and gain access to higher education. It is observed that despite the deteriorating situation and job procedures, participants also believe that education is a top priority for immigration. In fact, they would not consider immigration if the labor laws were modified to allow them to work and pay for their education costs in Jordan. Before fleeing to Jordan, the majority of the married couples had completed primary school. Some were unable to pursue their studies because they were responsible for their children's education. One of the key reasons for moving on to Europe is a lack of educational opportunities (DRC, 2016).

Syrian asylum seekers of varied ages, marital status, backgrounds, and lengths of stay in Jordan took part in this study. According to European Asylum Support Office (2016), asylum seekers' age, gender, familial circumstance, education, and skill levels, as well as the relationship to the household and community of origin, are all factors that play an important part in shaping migration decisions. The findings indicate that the majority of the young did not have the opportunity to study due to their living conditions, which compelled them to support their families. The data also shows that most married people, particularly women, are unemployed. Obstacles included not being of the appropriate working age, having work permission, or possessing the requisite qualifications, as well as the local culture around women's labor. Participants claimed that remaining in Jordan would be of no benefit to them but would make things worse. They believed that their family's future would begin in Europe, where they would be accepted and have their rights.

As demonstrated by the responses of the participants, various pull factors attract the Syrian asylum seekers to immigrate; education opportunities, better living conditions, safety and stability, healthcare services, and possible family reunification. Most interviewees believe that education in Europe is better and affordable, besides as a developed world, Europe offers better living conditions and a good income. In addition, they will not be treated as refugees and could own houses, cars, and driver's licenses. "Wage differentials may have a stronger influence on migration intentions..., good employment opportunities in the destination country and the presence of migrant networks" are crucial factors that pull Syrian to immigrate to Europe (as cited in European Asylum Support Office, 2016, p.11).

Haider (2016) as mentioned previously, summarized a list of seven major factors that contribute to Syrian secondary immigration to Europe. Although these factors were addressed in most interviews, just some were emphasized in the case of Syrian asylum seekers in Jordan. This explains how the host country in which Syrians reside plays such an important role in determining immigration's push and pull factors. Although this study comprises a variety of variables, still the broad umbrella of Syria asylum seekers' immigration is the main concern throughout the entire procedure.

\section{Limitations}

This study sheds light on Syrian asylum seekers in Jordan's governorates outside camps, it has some limitations that should be noticed. First, only Syrians who arrived in Jordan after the Syrian crisis in 2011 and had a UNHCR certificate were chosen as samples; besides, their residence had to be outside of camps in urban areas. A number of Syrians who were in Jordan before the crisis were excluded. This study, however, did not cover all of Jordan's governorates; instead, it focused only on four. Therefore, the findings cannot be generalized to the whole Syrian asylum seekers population in Jordan. Second, although the majority of the interviews were conducted in person, due to the severity of the Coronavirus outbreak at the time of the interviews, some were conducted via online sources with the consent of the participants.

\section{Recommendations}

Further research on pull factors in Europe that motivate Syrian refugees to move is recommended. It is suggested that a study of refugees in camps be conducted to see if immigrant motivations are explored. 
Acknowledgments: This work was made possible by the support of the Andrew W. Mellon Foundation through the Fellowship Program for Emerging Displaced Scholars. I would also like to acknowledge the tremendous support received from Professor Goleen Samari in the Heilbrunn Department of Population and Family Health, Columbia University Mailman School of Public Health.

Conflicts of Interest: The authors declare no conflict of interest.

\section{References}

[1] ACAPS. (2020). Overview Syrian Refugees. Accessed March 15, 2021, https://www.acaps.org/country/jordan/crisis/syrian-refugees

[2] Achilli, L. (2015). Syrian Refugees in Jordan: A Reality Check. Migration Policy Center. Policy Briefs (2).

[3] Braun, V., \& Clarke, V. (2006). Using Thematic Analysis in Psychology. Qualitative Research in Psychology, 3(2): 77-101.

[4] Brekke, J. P. \& Aarset. M. F. (2009). Why Norway? Understanding Asylum Destinations. Institute for Social Research, Report 2009: 12. Accessed April 27, 2021. https://samfunnsforskning.brage.unit.no/samfunnsforskning-xmlui/handle/11250/177523

[5] Boulby, M., \& Christie, K. (Eds.) (2018). Migration, Refugees, and Human Security in the Mediterranean and MENA. Switzcherland: Springer.

[6] CARE Jordan. (2021). 10 Years into Exile: A Shock on Top of a Crisis. A Summary of the 2020 Annual Assessment, January. Accessed June 5, 2021. https://data2.unhcr.org/en/documents/details/85533

[7] Caselli, M. (2019). Let Us Help Them at Home: Policies and Misunderstandings on Migrant Flow Across the Mediterranean Border. Journal of International Migration and Integration, 20(4): 983-993.

[8] Crawley, H., \& J. Hagen-Zanker, J. (2019). Deciding Where to Go: Policies, People and Perceptions Shaping Destination Preferences. International Migration, 57(1): 20-35.

[9] Creswell, J. W. (2002). Research Designed: Qualitative, Quantitative, and Mix-methods Approaches. 2nd edition. Thousand Oaks, CA: Sage Publications.

[10] Danish Refugee Council (DRC). (2016). Going to Europe: A Syrian Perspective. The Middle East \& North Africa, Regional Report, DRC. Accessed February 9, 2021. https://reliefweb.int/report/lebanon/middle-east-and-north-africa-regional-report-2016-going-europe-syrian-perspective

[11] Dekker, R., Engbersen, G., Klaver, J., \& Vonk, H. (2018). Smart Refugees: How Syrian Asylum Migrants Use Social Media Information in Migration Decision-Making. Social Media and Society, 4(1), 2056305118764439.

[12] Diab, J. L. (2021). Asylum, Repatriation, and Border Management During a Pandemic: The Case of Syrian Refugees in Lebanon. The Critical Refugee Studies Collective, University of California.

[13] European Asylum Support Office. (2016). The Push and Pull Factors of Asylum-Related Migration: A Literature Review. Accessed January 30, 2021. https://easo.europa.eu/sites/default/files/publications/The\%20Push\%20and\%20Pull\%20Factors\%20of\%20Asylum\%20\%20Related\%20Migration.pdf

[14] Fargues, P., \& Fandrich, C. (2012). The European Response to the Syrian Refugee crisis: what next? Accessed January $28,2021$. https://cadmus.eui.eu/bitstream/handle/1814/24836/MPC RR2012-14.pdf

[15] Fedyuk, O., \& Zentai, V. (2018). The interview in migration studies: a step towards dialogue and knowledge co-production?. In Qualitative Research in European Migration Studies (171-188). Springer, Cham.

[16] Global Forced Migration, (2020). Accessed February 14, 2021. https://reliefweb.int/sites/reliefweb.int/files/resources/2020\%20SFRC\%20Report\%20-\%20Global\%20Forced\%20Migration\%20\%20The\%20Political\%20Crisis\%20of\%200ur\%20Time-2-compressed.pdf

[17] Groth, A. (2016). A stronger European Response to the Syrian Refugee Crisis. Committee on Migration, Refugees and Displaced Persons Rapporteur. Council of Europe. Accessed January 25, 2021. https://reliefweb.int/sites/reliefweb.int/files/resources/Rapport-Groth-EN.pdf

[18] Hager, A. (2021). What Drives Migration to Europe? Survey Experimental Evidence from Lebanon. International Migration Review, 55(3): 929950.

[19] Haider, H. (2016). Syrian Refugee Onward Migration from Jordan to Europe. Research Report. Brighton, UK: Institute of Development Studies, 1-12.

[20] Hartberg, M. (2016). Drivers of Despair: Refugee Protection Failures in Jordan and Lebanon. Norwegian Refugee Council. Accessed January 18, 2021. https://www.nrc.no/globalassets/pdf/reports/drivers-of-despair.pdf

[21] Jordan INGO Forum (JIF). (January 2018). Syrian Refugees in Jordan: A Protection Overview. Accessed January 8, 2021. https://reliefweb.int/report/jordan/syrian-refugees-jordan-protection-overview-january-2018

[22] Jordan Response Plan for the Syria Crisis. (2020-2022). Accessed January 1, 2021. https://reliefweb.int/report/jordan/jordan-response-plansyria-crisis-2020-2022

[23] Jordan: Statistics for Registered Syrian Refugees (as of 31 January 2021) Accessed May 7, 2021. https://data2.unhcr.org/en/documents/details/84576

[24] Keogh, G. (2013). Modeling asylum migration pull-force factors in the EU-15. The Economic and Social Review, 44(3), 371-399. Accessed March 27, 2021. http://ezproxy.cul.columbia.edu/login?url=https://www-proquest-com.ezproxy.cul.columbia.edu/scholarlyjournals/modelling-asylum-migration-pull-force-factors-eu/docview/1459224327/se-2?accountid=10226

[25] Koser, K and Charles P (2002), The social networks of asylum seekers and the dissemination of information about countries of asylum. Migration Research Unit, University College, London.

[26] Kouider, M. (2021). Syrian Secondary Migration: A study on push and pull factors behind the irregular migration of Syrians from Turkey to Europe. (Dissertation). Accessed August 30, 2021, http://urn.kb.se/resolve?urn=urn:nbn:se:mau:diva-40330

[27] Kvittingen, A., Valenta, M., Tabbara, H., Baslan, D., \& Berg, B. (2019). The Conditions and Migratory Aspirations of Syrian and Iraqi Refugees in Jordan. Journal of Refugee Studies, 32 (1): 106-124.

[28] Lenner, K., \& Schmelter, S. (2016). Syrian Refugees in Jordan and Lebanon: Between Refuge and Ongoing Deprivation. IEMed Mediterranean Yearbook, 122-126. 
[29] Lyngstad, M. O. (2015). Refuge Beyond Safety: A Study on Syrian Refugees in Jordan Preparing for Irregular Onwards Travel to Europe. Accessed December 28, 2020. https://www.diva-portal.org/smash/get/diva2:1482744/FULLTEXT01.pdf

[30] Malkawi, K. (2015). World Should Not Take Jordan's Generosity for Granted - Officials, Relief Workers. Jordan Times. Accessed April 12, 2021. http://www.jordantimes.com/news/local/world-should-not-take-jordan\%E2\%80\%99s-generosity-granted-\%E2\%80\%94-officials-reliefworkers

[31] Mandic, D. (2017). Trafficking and Syrian Refugee Smuggling: Evidence from the Balkan Route. Social Inclusion, 5(2): 28-38. doi:10.17645/si.v5i2.917

[32] Neumayer, E. (2005a). Bogus Refugees? The Determinants of Asylum Migration to Western Europe. International Studies Quarterly, 49. 389409.

[33] Sadek, G. (2013). Legal Status of Refugees: Egypt, Jordan, Lebanon, and Iraq. Law Library of Congress, Global Legal Research Center. Accessed March 29, 2021. https://www.ecoi.net/en/file/local/1179540/1930 1391766387 2014-010156-rpt.pdf

[34] Saliba, I. (2016). Jordan. Law Library of Congress, U. S. G. L. R. D. Refugee Law, and Policy in Selected Countries. Refugee Law and Policy in Selected Countries (197-200). Law Library of Congress, Global Legal Research Center. Accessed April 3, 2021, https://irp.fas.org/congress/2016 rpt/lloc-refugee.pdf

[35] Syria Regional Refugee Response. (February 28, 2021). Accessed March 1, 2021, https://data2.unhcr.org/en/situations/syria/location/36

[36] Smith, R., \& Smith, L. (2018). Qualitative Methods. In Research Methods in Human Rights, edited by L. McConnell, and R. Smith. (1st ed.), (70-93). Routledge. https://doi.org/10.4324/9781315672632

[37] Taherdoost, H. (2016). Sampling Methods in Research Methodology; How to Choose a Sampling Technique for Research. International Journal of Academic Research in Management, 5(2): 18-27.

[38] Tanner, A. (2014). Push and Pull in Migration-a Systems Approach Revisited in a Contemporary Context. Siirtolaisuus-Migration, 41(1): 4045.

[39] Tiltnes, Å. A., Zhang, H., \& Pedersen, J. (2019). The Living Conditions of Syrian Refugees in Jordan. FAFO Report.

[40] UN High Commissioner for Refugees (UNHCR), (2018). Submission by the United Nations High Commissioner for Refugees For the Office of the High Commissioner for Human Rights' Compilation Report Universal Periodic Review: Jordan, July 2018, 3rd Cycle. Accessed January 7, 2021. https://www.refworld.org/docid/5b56fce37.html

[41] UNESCO, Glossary of Migration Related Terms, (2017). Accessed June 9, 2021. www.unesco.org/shs/migration/glossary

[42] UNHCR, (2020). Syria Emergency. Accessed July 6, 2021. https://www.unhcr.org/syria-emergency.html

[43] UNHCR, (February 2021). Resettlement Dashboard for Jordan. Accessed June 27, 2021. https://data2.unhcr.org/en/documents/details/85753

[44] UNHCR, (January-December 2019). Europe Resettlement. Accessed July 5, 2021. https://data2.unhcr.org/en/documents/details/77244

[45] World Bank. (2018). Jordan Housing Sector Review. Washington D.C. Accessed July 14, 2021, https://documents1.worldbank.org/curated/en/855101555960778525/pdf/Jordan-Housing-Sector-Assessment-Housing-Sector-Review.pdf

[46] Yahya, M., Kassir, J., \& El-Hariri, K. (2018). Unheard voices: What Syrian refugees need to return home. Washington, DC: Carnegie Endowment for International Peace.

[47] Zapata-Barrero, R., \& Yalaz, E. (2018). Qualitative Research in European Migration Studies. Springer Nature. 